\title{
The effect of progesterone replacement on gene expression in the corpus luteum during induced regression and late luteal phase in the bonnet monkey (Macaca radiata)
}

\author{
Padmanaban S Suresh, Kadthur C Jayachandra, Rudraiah Medhamurthy*
}

\begin{abstract}
Background: In higher primates, although LH/CG play a critical role in the control of corpus luteum (CL) function, the direct effects of progesterone (P4) in the maintenance of $C L$ structure and function are unclear. Several experiments were conducted in the bonnet monkey to examine direct effects of P4 on gene expression changes in the $\mathrm{CL}$, during induced luteolysis and the late luteal phase of natural cycles.

Methods: To identify differentially expressed genes encoding PR, PR binding factors, cofactors and PR downstream signaling target genes, the genome-wide analysis data generated in $\mathrm{CL}$ of monkeys after $\mathrm{LH} / \mathrm{P}_{4}$ depletion and $\mathrm{LH}$ replacement were mined and validated by real-time RT-PCR analysis. Initially, expression of these P4 related genes were determined in $\mathrm{CL}$ during different stages of luteal phase. The recently reported model system of induced luteolysis, yet capable of responsive to tropic support, afforded an ideal situation to examine direct effects of P4 on structure and function of CL. For this purpose, P4 was infused via ALZET pumps into monkeys $24 \mathrm{~h}$ after LH/P4 depletion to maintain mid luteal phase circulating P4 concentration (P4 replacement). In another experiment, exogenous P4 was supplemented during late luteal phase to mimic early pregnancy.

Results: Based on the published microarray data, 45 genes were identified to be commonly regulated by LH and P4. From these 19 genes belonging to PR signaling were selected to determine their expression in $L H / P_{4}$ depletion and P4 replacement experiments. These 19 genes when analyzed revealed 8 genes to be directly responsive to P4, whereas the other genes to be regulated by both $\mathrm{LH}$ and P4. Progesterone supplementation for $24 \mathrm{~h}$ during the late luteal phase also showed changes in expression of 17 out of 19 genes examined.
\end{abstract}

Conclusion: These results taken together suggest that P4 regulates, directly or indirectly, expression of a number of genes involved in the CL structure and function.

\section{Background}

In mammals, the secretion of progesterone $\left(\mathrm{P}_{4}\right)$ by corpus luteum (CL) is absolutely essential for establishment and, in some species, maintenance of pregnancy. In higher primates, $\mathrm{LH}$ and chorionic gonadotropin (CG) have been suggested to be the principal trophic factors responsible for $\mathrm{P}_{4}$ secretion in the CL [1]. Whether $\mathrm{P}_{4}$ plays a role in the maintenance of structure and function of CL has not been fully elucidated in higher

\footnotetext{
* Correspondence: rmm@mrdg.iisc.ernet.in

Department of Molecular Reproduction, Development and Genetics, Indian Institute of Science, Bangalore-560012, India
}

primates. Rothchild postulated that $\mathrm{P}_{4}$ is the primary stimulus of its own secretion and that intraluteal $\mathrm{P}_{4}$, among other effects such as control of structural integrity and steroidogenic capacity, is responsible for regulation of production of luteolysin, the prostaglandin (PG) $F_{2 \alpha}$, within the CL $[2,3]$. More recent studies have provided several lines of evidence, some of them with mechanistic insights, in support of the direct effects of $\mathrm{P}_{4}$ on CL. Expression of progesterone receptor (PR) isoforms in CL have been reported in several mammalian species [4-6]. Several studies have suggested that by way of its proliferative and anti-apoptotic actions, $\mathrm{P}_{4}$

\section{C) Biomed Central}

(c) 2011 Suresh et al; licensee BioMed Central Ltd. This is an Open Access article distributed under the terms of the Creative Commons Attribution License (http://creativecommons.org/licenses/by/2.0), which permits unrestricted use, distribution, and reproduction in any medium, provided the original work is properly cited. 
functions as survival factor of CL in human [7], rat [8-10], and cattle $[11,12]$. Like other steroid nuclear receptors, PR utilizes a plethora of cofactors termed coactivators or corepressors to regulate gene expression [13]. The PR cofactors identified to date include coactivators like (SRC1-3, CBP/p300 and NCOA1-3) [13] and corepressors like NCOR1-2 involved in modulation of PR activity in vivo $[14,15]$.

We have recently standardized a GnRH R antagonistinduced luteolysis model system in the monkey in which induced luteolysis could be reversed by exogenous LH administration [16]. Employing this model system, microarray analysis of differentially expressed genes in CL tissue during induced luteolysis and LH replacement following induced luteolysis has been determined [16]. The GnRH R antagonist-induced regressed CL with ablated $\mathrm{LH}$ action, yet capable of responding to $\mathrm{LH}$ replacement, affords an ideal situation to examine direct effects of $\mathrm{P}_{4}$ on CL structure and function. Extensive tissue remodeling with breakdown and renewal of extracellular matrix (ECM) that occurs during spontaneous luteolysis requires participation of matrix metalloproteinases (MMPs) and their tissue inhibitors, TIMPs [17-19]. It has been reported that decrease in $P_{4}$ levels during late luteal phase of the non fertile cycle is associated with changes in expression of ECM regulators [20]. It remains to be determined whether $\mathrm{P}_{4}$ regulates expression of tissue proteinases, especially following conception. The purpose of this study was to examine effects of $\mathrm{P}_{4}$ action on gene expression changes and function of CL. Experiments were carried out to determine expression of genes in CL tissue that encode different elements of PR complex and few downstream targets of PR activation throughout the luteal phase, after $\mathrm{LH} / \mathrm{P}_{4}$ depletion, after $\mathrm{P}_{4}$ replacement and after $\mathrm{P}_{4}$ supplementation during the late luteal phase.

\section{Methods}

Reagents

Oligonucleotide primers were synthesized by SigmaGenosys, Bangalore, India. DyNAzyme ${ }^{\mathrm{TM}}$ II DNA polymerase (F-501L) was purchased from Finnzymes, Espoo, Finland. Moloney murine leukemia virus (MMuLV) reverse transcriptase (RT) and $100 \mathrm{bp}$ DNA ladder were obtained from MBI Fermentas GmbH (St. Leon-Rot, Germany). Power SYBR ${ }^{\circledR}$ Green PCR master mix was obtained from Applied Biosystems, Foster City, CA, USA. GnRH R antagonist [Cetrorelix ${ }^{\circledR}$; (CET)] was a kind gift from Asta Medica, Frankfurt, Germany. ALZET $^{\circledR}$ Osmotic pump Model 2ML1 (infusion rate $10 \mu \mathrm{l} / \mathrm{h}$ ) was obtained from Alza Corporation, Palo Alto, CA. Antibodies specific to phospho-p38 (9211), phospho-p42/44 MAPK (9101), p38 MAPK (9212), p42/44 MAPK (9102), pMKK3/6 (9231), p38 MAPK assay kit
(9820), MMP-9 (G657) and Phototype-HRP Western detection system with horseradish peroxidase-linked anti-rabbit IgG (7071) were purchased from Cell Signaling Technology, Inc. Danvers, MA. Antibodies specific to PR (sc-538), NCOA1 (sc-8995), NCOA2 (also designated as GRIP1; sc-8996), NCOA3 (sc-25742) were procured from Santa Cruz Biotechnology, Santa Cruz, CA. Crystalline $\mathrm{P}_{4}$ (P0130) and all other reagents were purchased from Sigma Aldrich Corp. St. Louis, MO or sourced locally.

\section{Animal protocols, blood samples and $\mathrm{CL}$ collection}

Experimental protocols involving monkeys in this study were approved by the Institutional Animal Ethics Committee of the Indian Institute of Science, Bangalore. Adult female bonnet monkeys (Macaca radiata) weighing $3.3-5.1 \mathrm{~kg}$ were utilized for the study. The general care and housing of monkeys have been described elsewhere [21]. In this study, one day after occurrence of peak $E_{2}$ surge was designated as day 1 of the luteal phase, and CL was collected on designated days of the luteal phase and/or after administration of different treatments (see below). To retrieve CL from experimental monkeys, ovaries were accessed by performing laparotomy under aseptic conditions on ketamine hydrochloride $(15 \mathrm{mg} / \mathrm{kg} \mathrm{BW})$ and/or pentobarbital sodium (8-12 $\mathrm{mg} / \mathrm{kg}$ BW) anesthetized monkeys. Under sterile conditions, the excised CL was transferred to a petri dish containing filter paper, wiped dry, weighed, cut into 4-5 pieces, placed in individual sterile cryovials, snap-frozen in liquid nitrogen and stored at $-70^{\circ} \mathrm{C}$ until analysis.

\section{Experiment 1: Examination of differentially expressed genes during induced luteolysis and LH replacement experiments}

In order to identify genes associated with $\mathrm{LH}$ and $\mathrm{P}_{4}$ receptor signaling, the microarray data of induced luteolysis $\left(\mathrm{LH} / \mathrm{P}_{4}\right.$ depletion) and rescue of $\mathrm{CL}$ function by exogenous $\mathrm{LH}$ replacement studies deposited (\#GSE7827 and \#GSE8371) by us previously were examined. The main focus was on identifying changes in expression of genes associated with PR and genes downstream of PR signaling. For this purpose, various cofactors and corepressors (NCOA1-3, NCOR1-2, FKBP4 and FKBP5) of PR were selected for analysis. Expression of MMP-2 and 9, TIMP-3, ADAMTS-1, PGRMC1, BMP5, CDH2, WNT7A, HOXA1, IHH genes regarded as downstream target of gonadotropin and/or PR signaling in $\mathrm{CL}$ and in traditional $\mathrm{P}_{4}$ target tissues such as uterus were also examined [19,22-26]. The expanded forms of gene symbols used in this study are provided in Table 1. Real time RT-PCR analysis was carried out on RNA samples isolated from 
Table 1 List of expanded forms of gene symbols used

\begin{tabular}{|c|c|c|}
\hline SI. No. & Gene symbol & Gene name \\
\hline 1 & $P R$ & Progesterone receptor \\
\hline 2 & PGRMC1 & $\begin{array}{l}\text { Progesterone receptor membrane } \\
\text { component } 1\end{array}$ \\
\hline 3 & FKBP4 & FK506 binding protein 4 \\
\hline 4 & FKBP5 & $\begin{array}{l}\text { FK506 binding protein 5/peptidyl-prolyl } \\
\text { cis-trans isomerase FKBP5-like (M. mulatta) }\end{array}$ \\
\hline 5 & NCOA1 & Nuclear receptor coactivator 1 \\
\hline 6 & NCOA2 & Nuclear receptor coactivator 2 \\
\hline 7 & NCOA3 & Nuclear receptor coactivator 3 \\
\hline 8 & NCOR1 & Nuclear receptor corepressor 1 \\
\hline 9 & NCOR2 & Nuclear receptor corepressor 2 \\
\hline 10 & WNT7A & $\begin{array}{l}\text { Wingless-type MMTV integration } \\
\text { site family, member } 7 \mathrm{~A}\end{array}$ \\
\hline 11 & AREG & Amphiregulin \\
\hline 12 & BMP5 & Bone morphogenetic protein 5 \\
\hline 13 & $\mathrm{CDH} 2$ & $\begin{array}{l}\text { Cadherin 2, type 1, N-cadherin } \\
\text { (neuronal)/cadherin-2-like (M. mulatta) }\end{array}$ \\
\hline 14 & HOXA1 & Homeobox A1 \\
\hline 15 & $\mathrm{IHH}$ & Indian hedgehog \\
\hline 16 & ADAMTS1 & $\begin{array}{c}\text { A disintegrin-like and metallopeptidase with thrombospondin type } 1 \text { motif, 1/ADAM } \\
\text { metallopeptidase with thrombospondin type } 1 \text { motif, } 1\end{array}$ \\
\hline 17 & MMP9 & Matrix metallopeptidase 9 \\
\hline 18 & MMP2 & Matrix metallopeptidase 2 \\
\hline 19 & TIMP3 & Tissue inhibitor of metalloproteinase 3/TIMP metallopeptidase inhibitor 3 ( $M$. mulatta) \\
\hline
\end{tabular}

CL tissues collected during luteolysis [VEH ( $\mathrm{n}=5$ animals) and $\mathrm{LH} / \mathrm{P}_{4}$ depletion ( $\mathrm{n}=5$ animals)] and $\mathrm{LH}$ rescue ( $\mathrm{LH}$ replacement, $\mathrm{n}=3$ animals each for PBS and $\mathrm{LH}$ treatments) of CL function experiments as reported previously [16].

\section{Experiment 2: Expression of various components of PR signaling complex and PR target genes throughout the luteal phase}

To study expression of PR, various components of PR signaling complex and some of the downstream target genes of PR signaling, corpora lutea ( $\mathrm{n}=3$ animals/ stage of luteal phase) were collected from monkeys at early (day 5), mid (day 8), and late (day 14) stage of the luteal phase of the menstrual cycle as reported previously [27]. Also, CL ( $\mathrm{n}=3$ animals) was collected from monkeys on day 1 of menstrual cycle (d1M), a time point when luteolytic events are manifested. Blood samples were collected from monkeys on the day of $\mathrm{CL}$ collection for determination of $\mathrm{P}_{4}$ concentration.

\section{Experiment 3: Effects of $\mathrm{P}_{4}$ replacement on expression of} $\mathrm{PR}$, coactivators, corepressors and $\mathrm{P}_{4}$ target genes during induced luteolysis

We have recently reported that replacement of $\mathrm{LH}$ post $\mathrm{LH} / \mathrm{P}_{4}$ depletion leads to brisk and sustained increase in $\mathrm{P}_{4}$ concentration suggesting rescue of $C L$ function following reestablishment of LH levels [16]. In the present experiments, we determined the direct effects of $\mathrm{P}_{4}$ on CL during absence of luteotrophic stimulus. The different components of the PR signaling complex and expression of few genes considered as target of PR activation were examined. In experiment 3.1 , with a view to mimic mid luteal phase circulating $\mathrm{P}_{4}$ concentration, exogenous $\mathrm{P}_{4}$ was administered through implantation of $\mathrm{P}_{4}$ filled ALZET pumps to monkeys depleted of $\mathrm{LH} / \mathrm{P}_{4}$ $\left(\mathrm{P}_{4}\right.$ replacement model). For this purpose, pilot experiments were carried out in adult female monkeys to examine the feasibility of providing $\mathrm{P}_{4}$ as continuous infusion by way of implantation of $\mathrm{P}_{4}$ filled ALZET pump. Keeping in mind the limitation on use of organic solvents compatible with the pump, initially $16 \mathrm{mg}$ of $\mathrm{P}_{4}$ was dissolved in $300 \mu \mathrm{l}$ of ethanol and the solution was made up to $2 \mathrm{ml}$ by propylene glycol and the entire solution was transferred to 2 ML1 ALZET pump. It was determined that three, $32.5 \mathrm{mg}$ of $\mathrm{P}_{4}$ filled pumps that provided infusion of $487.5 \mu \mathrm{g} / 30 \mu \mathrm{l} / \mathrm{h}$, were required to be implanted in anesthetized monkeys to establish circulating $\mathrm{P}_{4}$ concentration higher or in the range of mid luteal phase concentration. In order to determine the time course of $\mathrm{P}_{4}$ secretion immediately before and at different time intervals after injection of CET $\left(\mathrm{LH} / \mathrm{P}_{4}\right.$ depletion), monkeys on day 7 of the luteal phase $(n=3$ animals) were administered CET $(150 \mu \mathrm{g} / \mathrm{kg} \mathrm{BW}$, s.c.) 
and blood samples were collected twice daily until onset of menses. In experiment 3.2, three groups of monkeys ( $\mathrm{n}=3-4$ animals/group) were administered $5.25 \%$ glucose (vehicle for CET treatment; VEH; group 1), CET

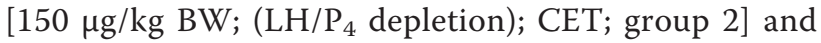
CET $(150 \mu \mathrm{g} / \mathrm{kg} \mathrm{BW})$ followed $24 \mathrm{~h}$ later with implantation of $\mathrm{P}_{4}$ filled three ALZET pumps designed to infuse $487.5 \mu \mathrm{g}$ of $\mathrm{P}_{4} / 30 \mu \mathrm{l} / \mathrm{h}$ for $24 \mathrm{~h}\left[\mathrm{CET}+\mathrm{P}_{4}\right.$; $\left(\mathrm{P}_{4}\right.$ replacement); group 3]. Blood samples were collected immediately before and at different time intervals throughout the experiment. In group 3, ALZET pumps were removed $24 \mathrm{~h}$ later, and further blood samples were collected to monitor circulating $\mathrm{P}_{4}$ levels. Corpora lutea were retrieved from monkeys of all three groups (VEH, $\mathrm{CET}$ and $\left.\mathrm{CET}+\mathrm{P}_{4}\right)$.

\section{Experiment 4: Effects of $\mathrm{P}_{4}$ supplementation on $\mathrm{CL}$ function during late luteal phase}

An experiment was conducted to gain insight into direct effects of increased $\mathrm{P}_{4}$ during rescue of $\mathrm{CL}$ function that occurs during late luteal phase of the fertile menstrual cycle. On day 13 of the luteal phase of non-mated females, three $\mathrm{P}_{4}$ filled ALZET pumps (97.5 $\mathrm{mg}$ of $\mathrm{P}_{4}$ ) were implanted for $24 \mathrm{~h}, \mathrm{CL}$ ( $\mathrm{n}=3$ animals) was harvested and the pumps were removed $24 \mathrm{~h}$ later. Blood samples were collected immediately before and at different time intervals during implantation and after retrieval of CL as well as removal of implants for determining the $\mathrm{P}_{4}$ secretion pattern. For purposes of comparison, $\mathrm{CL}$ ( $\mathrm{n}=3$ animals) was harvested from untreated monkeys (untreated control) on day 14 of the luteal phase of the menstrual cycle.

\section{RNA isolation}

Total RNA was isolated from CL tissues obtained from different experiments using TRI reagent according to manufacturer's instructions. RNA samples were analyzed using NanoDrop ND-1000 UV-VIS spectrophotometer and samples with $\mathrm{A}_{260} / \mathrm{A}_{280}$ values 1.8 - 1.9 were selected for further analyses.

\section{Real-time RT-PCR analysis}

Real time RT-PCR analysis was carried out as described previously [16]. Total RNA (1 $\mu \mathrm{g})$ extracted from CL of monkeys from various experiments were reverse transcribed using MMuLV RT in Eppendorf mastercycler, epgradient PCR machine. Briefly, In a $20 \mu$ total reaction, $1 \mu \mathrm{g}$ of total RNA along with $1 \mu \mathrm{l}$ of Oligo dT primer were incubated at $65^{\circ} \mathrm{C}$ for $10 \mathrm{~min}$ and then snap chilled on ice for $5 \mathrm{~min}$. To this RNA-Oligo dT hybrid, a cocktail containing $4 \mu \mathrm{l}$ of $5 \mathrm{X}$ RT buffer $[250 \mathrm{mM}$ Tris $\mathrm{HCl}\left(\mathrm{pH} 8.3\right.$ at $25^{\circ} \mathrm{C}$ ), $250 \mathrm{mM} \mathrm{KCl}, 20 \mathrm{mM} \mathrm{MgCl}_{2}$ and $10 \mathrm{mM}$ DTT], $10 \mathrm{mM}$ dNTPs and DEPC treated water were added followed by addition of 200 units
$(1 \mu \mathrm{l})$ of Revert Aid ${ }^{\mathrm{TM} M M u L V} \mathrm{RT}$ enzyme. The reaction mixture was incubated at $42^{\circ} \mathrm{C}$ for $60 \mathrm{~min}$. The resulting cDNAs were used as template for real time RT-PCR analysis using gene specific primers. The primer pairs were designed using Rhesus macaque sequences submitted at NCBI and ENSEMBL using Primer Express software v2.0 (Applied Biosystems, Foster City, CA, USA) spanning the exon-exon junction. The diluted cDNA samples equivalent to $10 \mathrm{ng}$ of total RNA were subjected to analysis in Applied Biosystems 7500 Fast Real Time PCR system with SDS v 1.4 program employing Power SYBR green 2X PCR master mix. The $10 \mu \mathrm{l}$ real time RT-PCR mixture contained cDNA equivalent to $10 \mathrm{ng}$ of total RNA, $5 \mu \mathrm{l}$ of PCR master mix and $5 \mu \mathrm{M}$ each of forward and reverse gene specific primers. The initial denaturation was carried out at $95^{\circ} \mathrm{C}$ for $10 \mathrm{~min}$, with further 40 cycles of denaturation $\left(95^{\circ} \mathrm{C}\right.$ for $30 \mathrm{sec}$ ), annealing (specific annealing temperature for $30 \mathrm{sec})$ and extension $\left(72^{\circ} \mathrm{C}\right.$ for $\left.30 \mathrm{sec}\right)$ with a final extension of $5 \mathrm{~min}$ at $72^{\circ} \mathrm{C}$. PCR reactions were carried out in duplicates in 96 well plates. For each gene a no template control (NTC) was included and dissociation/ melting curves were generated to determine the specificity of primers. Real time RT-PCR data for each gene was normalized using L19 expression level as internal control within each cDNA sample. The fold change in expression of the genes was determined using the $\Delta \Delta C_{t}$ method, which calculates the fold change using the formula: Fold change $=2^{-\Delta \Delta C t}$, where $C_{t}=$ Threshold cycle i.e. the cycle number at which the relative fluorescence of test samples increases above the background fluorescence and $\Delta \Delta \mathrm{C}_{\mathrm{t}}=\left[\mathrm{C}_{\mathrm{t}}\right.$ gene of interest (treated sample)$C_{t}$ of L19 (treated sample)] - $\left[C_{t}\right.$ gene of interest (control sample)- $C_{t}$ of L19 (control sample)]. The list of genes and details of the primers employed in the real time RT-PCR analysis along with the annealing temperature and expected product size are provided in Table 2.

\section{Hormone assays}

$E_{2}$ and $P_{4}$ concentrations in serum were determined by specific RIA as reported previously [21].

\section{Immunoblotting analysis}

Immunoblot analyses and in vitro P38MAPK (P38) assays of CL tissue lysates were carried out as per published procedures. Assays were carried out with equal amount of protein lysates from the luteal tissue of various treatments as reported previously from the laboratory [27].

\section{Statistical analysis}

Data were expressed as mean \pm SEM. Statistical evaluation of mean differences of serum $\mathrm{P}_{4}$ concentrations and realtime RT-PCR expression among different experimental 
Table 2 List of Primers used for real time RT-PCR analysis

\begin{tabular}{|c|c|c|c|c|}
\hline S. No. & Gene name & Primer sequence ( $5^{\prime}$ to $\left.3^{\prime}\right)$ & Annealing temp $(O C)$ & Product size (bp) \\
\hline \multirow[t]{2}{*}{1} & PR F & GCCACATTCAACACCCACTT & 57.4 & 134 \\
\hline & PR R & CCTTCAGCTCAGTCATGACG & & \\
\hline \multirow[t]{2}{*}{2} & NCOA1 F & CTGCACGTGGGGGATCAT & 60.4 & 146 \\
\hline & NCOA1 R & CCTGGCTCATCTGGAGGGT & & \\
\hline \multirow[t]{2}{*}{3} & $\mathrm{NCOA} 2 \mathrm{~F}$ & CATGACCTCAGTGACCTCCGT & 60.4 & 116 \\
\hline & NCOA2 R & CCATTCCAGGCAGCTGGTTT & & \\
\hline \multirow[t]{2}{*}{4} & NCOA3 F & CACCACAGGGCAGATGAGTG & 60.4 & 135 \\
\hline & NCOA3 R & TGTGGGGGGCTACTCATG & & \\
\hline \multirow[t]{2}{*}{5} & NCOR1 F & GCATCGAGCTGCTGTTATCCC & 62.9 & 145 \\
\hline & NCOR1 R & TCTCTGCCGCTGCTCCTCC & & \\
\hline \multirow[t]{2}{*}{6} & NCOR2 F & AAGCAGCGAGCGGCTGCCAT & 72.6 & 143 \\
\hline & NCOR2 R & TGCTGAGGGGCGTCGCTCTC & & \\
\hline \multirow[t]{2}{*}{7} & FKBP4 F & GGGGACCGAGTCTTTGTCCACT & 69.9 & 124 \\
\hline & FKBP4 R & CCCAAGCCTTGATGACCTCCC & & \\
\hline \multirow[t]{2}{*}{8} & MMP-2 F & GCCACATTCTGGCCTGAGCT & 62.4 & 151 \\
\hline & MMP-2 R & CCAGGCTGGTCAGTGGCTTG & & \\
\hline \multirow[t]{2}{*}{9} & MMP-9 F & CTGGAGGTTCGACGTGAAG & 55 & 155 \\
\hline & MMP-9 R & AACTCACGCGCCAGTAGAAG & & \\
\hline \multirow[t]{2}{*}{10} & TIMP3 F & CAAGTACCAGTACCTGCTGACA & 55.4 & 122 \\
\hline & TIMP3 R & GATAGTTCAGCCCCTTGC & & \\
\hline \multirow[t]{2}{*}{11} & BMP5 F & CCTGAAGAGTCGGAGTACTCAG & 59.2 & 139 \\
\hline & BMP5 R & GACTCTGGGTGGTCAGAGGA & & \\
\hline \multirow[t]{2}{*}{12} & $\mathrm{CDH} 2 \mathrm{~F}$ & CATCCCTCCAATCAACTTGCC & 59.2 & 131 \\
\hline & $\mathrm{CDH} 2 \mathrm{R}$ & GAGGCTGGTCAGCTCCTG & & \\
\hline \multirow[t]{2}{*}{13} & HOXA1 F & CTTCGCAGGACCAGGTCACTC & 65.1 & 124 \\
\hline & HOXA1 R & GGTCCGAGGGGTAGGCTCG & & \\
\hline \multirow[t]{2}{*}{14} & $\mathrm{HH} F$ & GCCGCGCGGTGGACATCA & 71.9 & 126 \\
\hline & $\mathrm{IHHR}$ & CGGAGCAATGCACGTGGGCC & & \\
\hline \multirow[t]{2}{*}{15} & FKBP5 F & GGTGAAGCCCAGCTGCTC & 66.7 & 114 \\
\hline & FKBP5 R & CTGGCACATGGAGATCTGC & & \\
\hline \multirow[t]{2}{*}{16} & PRMC1F & CGCCGCTCAACCTGCTGCT & 69.7 & 139 \\
\hline & PRMC1 R & GTGAAGTCGCGCCGCTTGAG & & \\
\hline \multirow[t]{2}{*}{17} & ADAMTS $1 \mathrm{~F}$ & GCCGACTGGGAAAGCGGA & 66.6 & 120 \\
\hline & ADAMTS $1 \mathrm{R}$ & CCAGTTCCTGTGGGCTGTCC & & \\
\hline \multirow[t]{2}{*}{18} & WNT7A F & AGCTGGGCTACGTGCTCAAGG & 68.2 & 138 \\
\hline & WNT7A R & CCAGGTCCGTGTCCATGGG & & \\
\hline \multirow[t]{2}{*}{19} & AREG $F$ & GTTGCCCCAGAGACCGAGACG & 72.6 & 113 \\
\hline & AREG $R$ & CAGCATAATGGCCTGAGCCGA & & \\
\hline \multirow[t]{2}{*}{20} & L19 F & GCCAACTCCCGTCAGCAGA & 60 & 154 \\
\hline & L19 R & TGGCTGTACCCTTCCGCTT & & \\
\hline
\end{tabular}

groups were analyzed by one-way ANOVA, followed by the Newman-Keuls multiple comparison tests (PRISM GraphPad, version 4.0; GraphPad Software Inc., San Diego, CA) and Student's t- test to compare between two groups. A P value of $<0.05$ was considered statistically significant. The linear regression analysis on microarray and real time RT-PCR data was done as reported earlier [16].

\section{Results}

Identification and validation of differentially expressed genes in $\mathrm{LH} / \mathrm{P}_{4}$ depletion and $\mathrm{LH}$ replacement experiments

The experimental details of CL collection from $\mathrm{LH} / \mathrm{P}_{4}$ depletion (CET-induced luteolysis) and $\mathrm{LH}$ replacement $(\mathrm{CET}+\mathrm{LH})$ models and the microarray data comparing 
these models deposited in NCBI's Gene Expression Ominibus (\#GSE7827 and \#GSE8371) have been described previously [16]. The published microarray data was mined for $\mathrm{P}_{4 \leftarrow}$ responsive genes, and 45 differentially expressed genes were identified based on criteria of $>1.5$ fold change in both $\mathrm{LH} / \mathrm{P}_{4}$ depletion and $\mathrm{LH}$ replacement experiments. We narrowed down to the 45 genes by comparing our previous data on LH replacement studies with $\mathrm{P}_{4}$-responsive genes reported in literature for other tissues $[28,29]$. From the 45 genes identified, 19 genes belonging to steroidogenesis and $\mathrm{P}_{4}$ target/regulation related genes (PR, PR binding proteins, cofactors, corepressors and some of the genes considered as downstream targets of PR activation) considered necessary for CL structure and function were selected for further studies. It should be noted that of the 19 genes, expression of only 12 genes was examined during different stages of the luteal phase in experiment 2 and expression of all 19 genes was determined in experiments 3 and 4 .

Figure 1A shows microarray and real time RT-PCR fold changes in expression of genes associated with PR signaling/regulation in CL tissue from monkeys of LH/ $\mathrm{P}_{4 \leftarrow}$ depletion and LH replacement models. Validation of microarray data from $\mathrm{LH} / \mathrm{P}_{4 \leftarrow}$ depletion model by real time RT-PCR analyses provided a good correlation in expression changes of most genes examined except for PR, NCOR1, and HOXA1 which showed higher expression changes in real time RT-PCR analysis, while expression of WNT7A and AREG genes showed inverse correlation by real time RT-PCR analysis (Figure 1A). The linear regression analysis on $\log _{2}$-transformed data of microarray and real time RT-PCR analyses suggested a good correlation $(R=0.5013, P=0.0484)$. A number of genes that were examined to be differentially expressed after $\mathrm{LH} / \mathrm{P}_{4 \leftarrow}$ depletion were found to be reversed following LH replacement (Figure 1B). Expression of $\mathrm{P}_{4 \leftarrow}$ responsive genes like PR, NCOA3, TIMP3, BMP5 and CDH2 was down regulated after LH replacement, whereas expression of genes like NCOR1, NCOR2 and MMP-9 was up regulated after LH replacement (Figure 1B). The microarray data and real time RT-PCR data for LH replacement experiments showed good correlation except for the observation of profound down regulation in BMP5 expression by microarray analysis than real time $\mathrm{RT}-\mathrm{PCR}$ analysis $(\mathrm{R}=0.7028, \mathrm{P}=$ 0.0312).

\section{Expression of PR cofactors and its downstream target genes throughout the luteal phase}

Real time RT-PCR analysis results of PR, NCOA1-3, NCOR1-2, FKBP5, TIMP 3, MMP-2, ADAMTS-1, IHH and HOXA1 in CL collected from different stages of luteal phase are represented in Figure 2A. In order to gain information on the fold expression changes during different stages, expression of each gene at early (E) stage was set as 1 and expression at other stages of luteal phase was represented as fold change in relation to the early stage. Corresponding to the waxing and waning levels of circulating $\mathrm{P}_{4}$ throughout different stages of the luteal phase, the expression of PR mRNA was not statistically different $(\mathrm{P}>0.05)$ across all the stages of luteal phase (Figure 2A). The protein expression for PR isoform B was low at early stage and its expression was high at all the other stages examined, with higher expression at mid luteal phase compared to early stage ( 1 vs $1.82 \pm 0.2$ fold; early vs mid stage, respectively; $\mathrm{P}<0.05$ ) (Figure $2 \mathrm{~B}$ ). However, the protein expression for PR isoform A was low at early and mid stage, and became higher at later stages of the luteal phase with late luteal stage being significantly higher (1 vs $1.45 \pm 0.06$ fold, early vs late stage, respectively; $\mathrm{P}<$ 0.05). The fold change in expression of NCOA1 mRNA and protein was low at early and mid stage (Figure 2A), and was significantly higher $(\mathrm{P}<0.05)$ in $\mathrm{CL}$ collected from monkeys on day 1 of menses ( 1 vs $3.62 \pm 0.04$ fold, early stage vs $\mathrm{d} 1 \mathrm{M}$, respectively; $\mathrm{P}<0.05)$. Expression of NCOA2 and NCOR2 mRNA was higher $(\mathrm{P}<$ $0.05)$ in the late stage CL compared to their expression at early, mid and $\mathrm{d} 1 \mathrm{M}$ stages (Figure $2 \mathrm{~A}$ ), and the protein expression for NCOA2 was high in mid stage CL. Expression changes of FKBP5 and NCOA3 mRNA did not vary significantly during different stages of luteal phase $(\mathrm{P}>0.05$; Figure $2 \mathrm{~A})$. The protein expression of NCOA3 was high in mid stage CL compared to early stage CL ( 1 vs $1.2 \pm 0.05$ fold, early vs mid stage, respectively; $\mathrm{P}<0.05$, Figure $2 \mathrm{~B})$. The fold change in expression of NCOR1 showed a progressive increase with expression being higher in CL of late stage and $\mathrm{d} 1$ $\mathrm{M}$ compared to other stages (Figure 2A). The expression of proteinase family genes such as TIMP3 and MMP-2 were higher in $\mathrm{CL}$ at late luteal stage compared to early and mid luteal stages. Expression of ADAMTS-1, IHH and HOXA1 in CL tissues collected at different stages of luteal phase did not vary significantly ( $\mathrm{P}>$ 0.05 ; Figure $2 \mathrm{~A}$ ).

\section{Effects of $\mathrm{P}_{4}$ replacement on expression of $\mathrm{PR}$,} coactivators and corepressors during induced luteolysis Circulating $\mathrm{P}_{4}$ concentrations were $3.8 \pm 0.3,1.5 \pm 0.07$, $0.6 \pm 0.1,0.56 \pm 0.01,0.5 \pm 0.04,0.3 \pm 0.05$ and $0.6 \pm$ $0.1 \mathrm{ng} / \mathrm{ml}$, respectively at $0,12,24,36,48,60$ and $72 \mathrm{~h}$ post $\mathrm{LH} / \mathrm{P}_{4}$ depletion (CET treatment; Figure $3 \mathrm{~A}$ ). All monkeys showed menses $96-120 \mathrm{~h}$ post $\mathrm{LH} / \mathrm{P}_{4}$ depletion. A brief outline of the experiment involving exogenous $\mathrm{P}_{4}$ replacement is presented in Figure $3 \mathrm{~B}$. The $\mathrm{P}_{4}$ concentration in monkeys combined from all three groups was $3.5 \pm 0.6 \mathrm{ng} / \mathrm{ml}$ prior to $\mathrm{VEH}(\mathrm{n}=3)$ or 


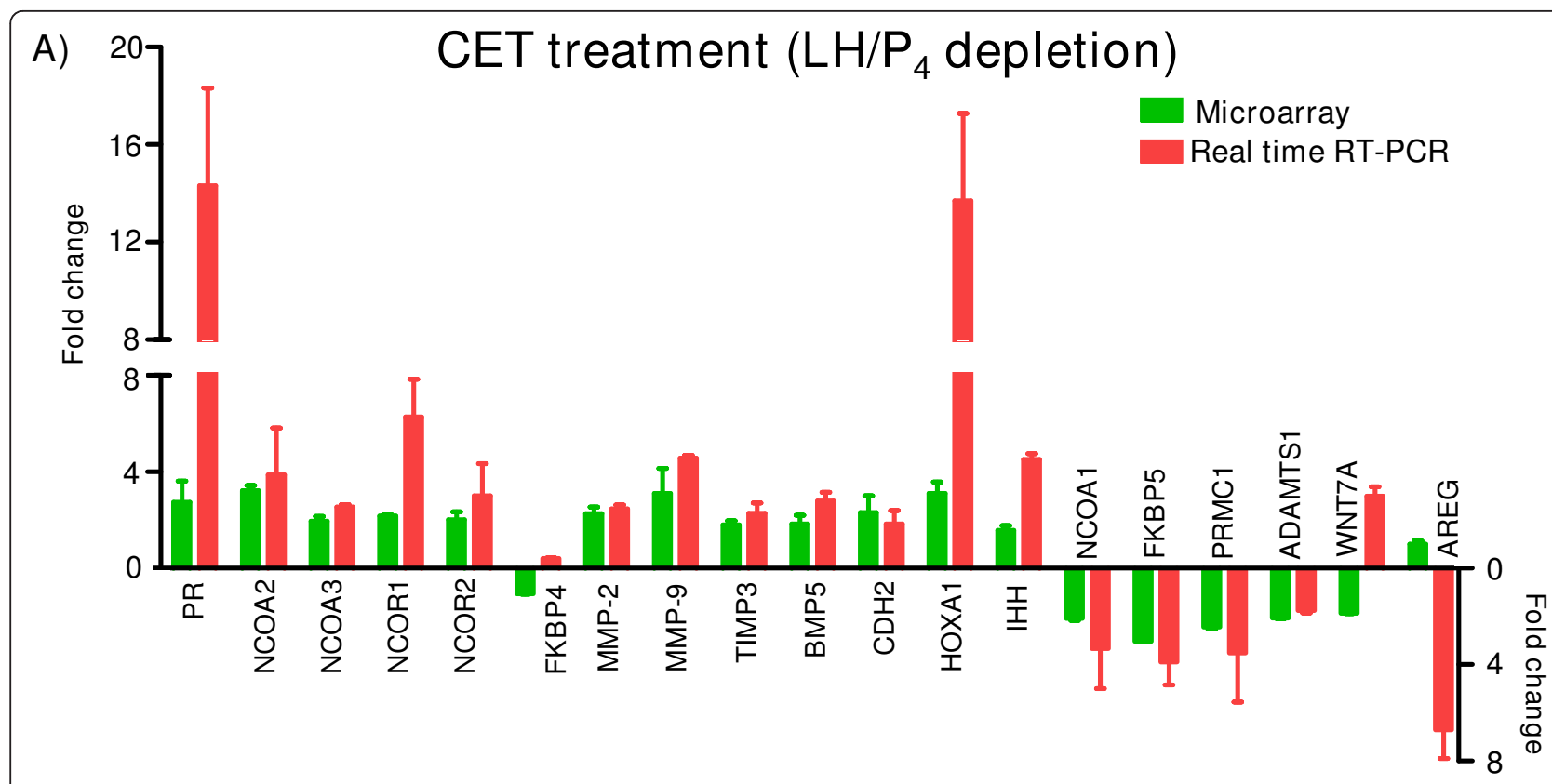

B) $\quad$ CET + LH treatment (LH replacement)

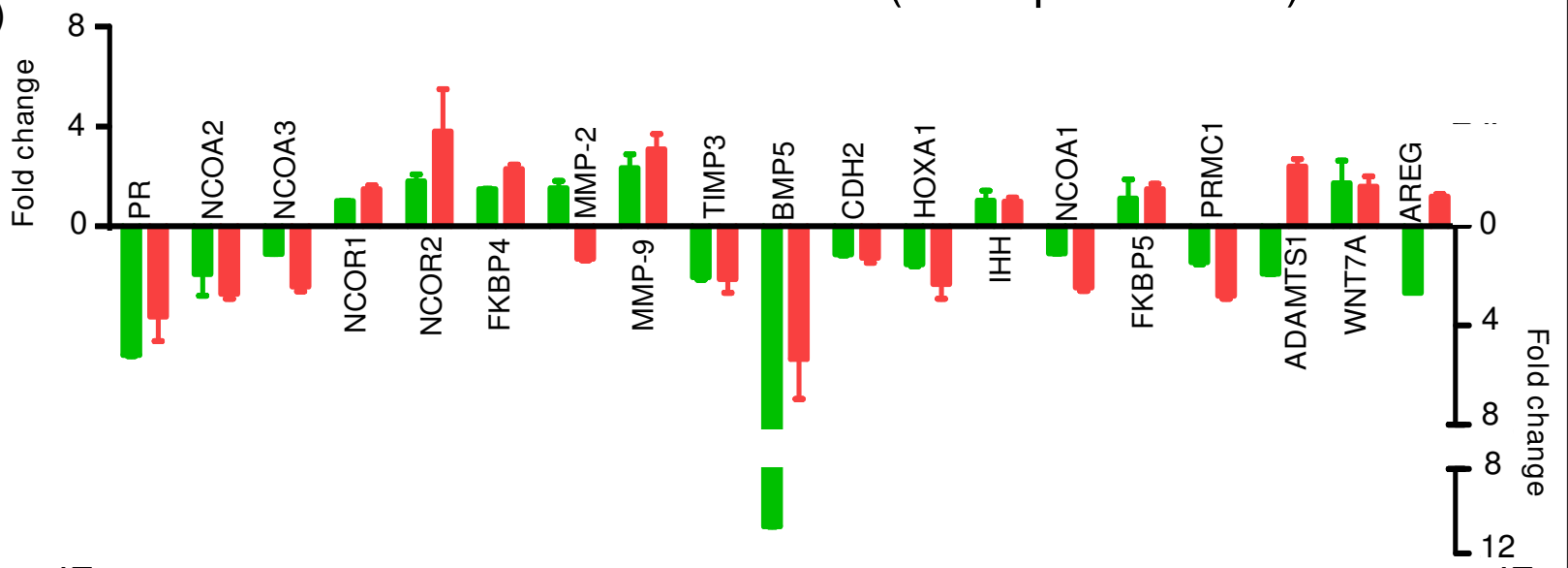

Figure 1 Microarray and real time RT-PCR expression analyses of genes associated with PR signaling/regulation in CL tissue from monkeys of $\mathrm{LH} / \mathrm{P}_{4 \Re}$ depletion and $\mathrm{LH}$ replacement models. (A) Effects of $\mathrm{LH} / \mathrm{P}_{4}$ depletion (CET treatment; $n=5$ animals each for VEH and CET treatments) and (B) LH replacement (CET+LH treatments; $n=3$ animals each for CET+PBS and CET+LH treatments) on gene expression changes in the CL tissue. Microarray data deposited at GEO with accession \#s GSE7827 and GSE8371 were analyzed. Expression of $\mathrm{P}_{4}$ responsive genes identified from the microarray data (i.e. having $>1.5$ fold cut off over VEH treatment) is expressed as fold expression change (mean \pm SEM) and further validated by real time RT-PCR analyses. The real time RT-PCR analysis was determined using $\triangle \Delta C_{t}$ method (see materials and methods). RT-PCR and microarray data are presented mean \pm SEM of fold change above control.

CET ( $\mathrm{n}=7$ ) treatment (Figure $3 \mathrm{C})$, and were maintained higher $(4.1 \pm 0.3$ and $4.98 \pm 0.3 \mathrm{ng} / \mathrm{ml})$ at 12 and $24 \mathrm{~h}$ after administration of $\mathrm{VEH}$, whereas $\mathrm{P}_{4}$ concentrations declined significantly 12 and $24 \mathrm{~h}$ post $\mathrm{LH} / \mathrm{P}_{4}$ depletion $(1.5 \pm 0.07$ and $0.6 \pm 0.1 \mathrm{ng} / \mathrm{ml}$ at 12 and $24 \mathrm{~h}$ respectively; $\mathrm{P}<0.05$, Figure $3 \mathrm{C}$ ). Replacement of $\mathrm{P}_{4}$ by way of implantation of $\mathrm{P}_{4}$ containing ALZET pumps at $24 \mathrm{~h}$ post CET treatment resulted in significant $(\mathrm{P}<$ 0.05 ) increase in $\mathrm{P}_{4}$ concentrations within $6 \mathrm{~h}$ post treatment and remained high throughout the $24 \mathrm{~h}$ duration of implantation. Upon removal of $\mathrm{P}_{4}$ containing ALZET pumps and lutectomy, $\mathrm{P}_{4}$ concentrations declined to reach $1.38 \pm 0.6$ and $0.76 \pm 0.17 \mathrm{ng} / \mathrm{ml}$ at 12 and $24 \mathrm{~h}$, respectively (Figure $3 \mathrm{C}$ ).

To analyze gene expression changes post $\mathrm{P}_{4}$ replacement, 19 genes were selected for real time RT-PCR analyses and the results were presented in Figure 4A. These genes were selected for analysis based on literature data from studies on classic $\mathrm{P}_{4}$ target organs, $\mathrm{P}_{4}$ responsive cell lines as well as from our microarray data of the LH/ 


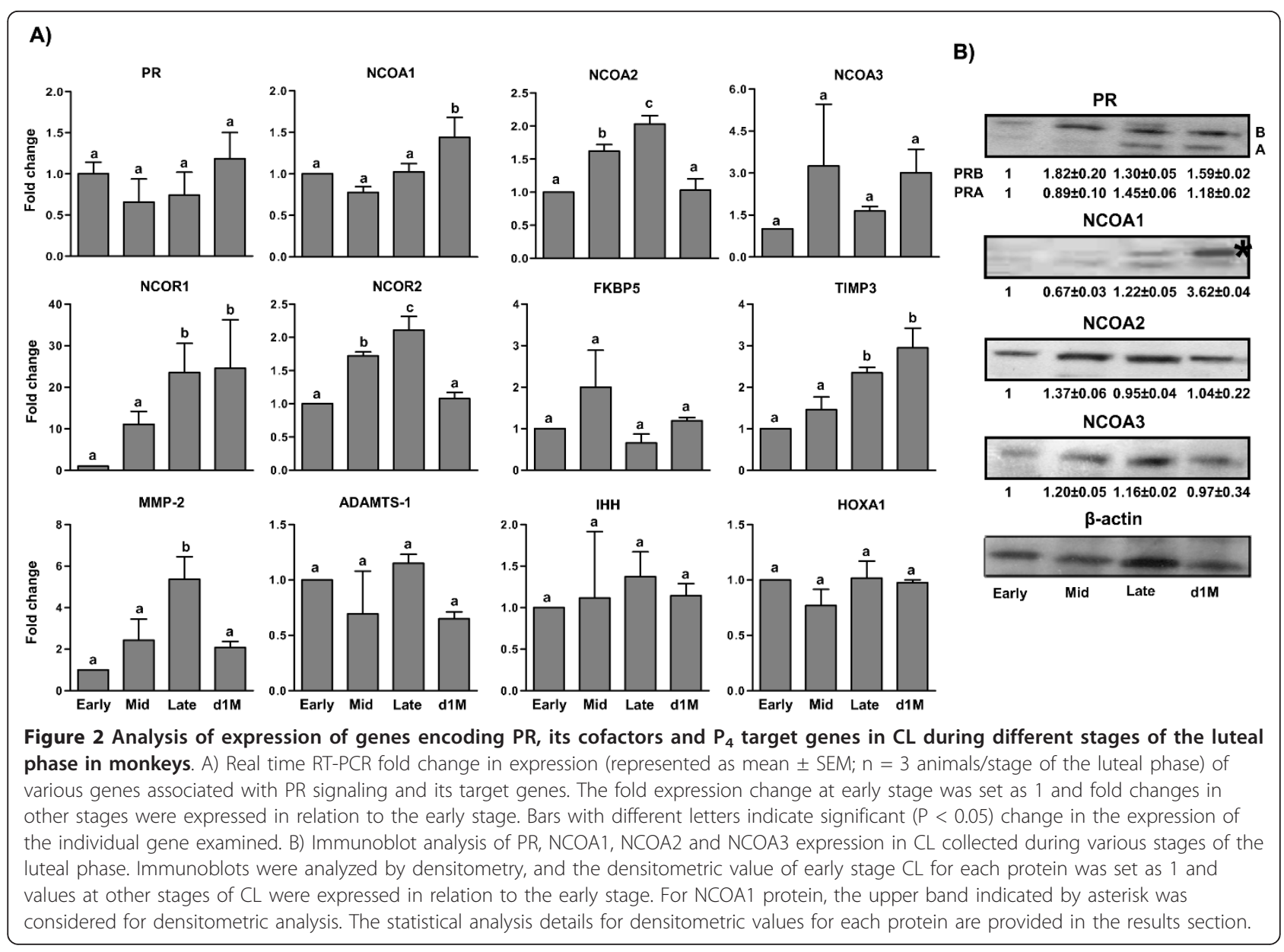

$\mathrm{P}_{4}$ depletion (CET induced luteolysis) experiments $[16,28,29]$. Initially the fold change in expression of PR mRNA was low in VEH treated monkeys, increased to 15 fold in $\mathrm{LH} / \mathrm{P}_{4}$ depletion model, and then decreased significantly $(\mathrm{P}<0.05)$ after $\mathrm{P}_{4}$ replacement (Figure $\left.4 \mathrm{~A}\right)$ suggesting $\mathrm{PR}$ to be a $\mathrm{P}_{4}$ target gene. Similar to pattern of PR mRNA expression, the protein expression of PR isoform $\mathrm{B}$ was low initially in $\mathrm{CL}$ of VEH treated monkeys and increased post $\mathrm{LH} / \mathrm{P}_{4}$ depletion (1 vs $2.72 \pm$ 0.04 fold VEH vs CET, respectively; $\mathrm{P}<0.05$; Figure $4 B$ ), while reduced post $\mathrm{P}_{4}$ replacement. However, the protein expression of PR isoform A was low in CL of $\mathrm{VEH}$ treated monkeys and remained low thereafter in both $\mathrm{LH} / \mathrm{P}_{4}$ depletion and $\mathrm{P}_{4}$ replacement conditions (Figure 4B). The fold change in expression of PGRMC1 and FKBP4 mRNA was significantly lower $(\mathrm{P}<0.05)$ after $\mathrm{LH} / \mathrm{P}_{4}$ depletion and no significant effect was observed after $\mathrm{P}_{4}$ replacement (Figure 4A). Expression of NCOA 1 mRNA decreased marginally after $\mathrm{LH} / \mathrm{P}_{4}$ depletion while $\mathrm{P}_{4}$ replacement increased its expression significantly by $3-4$ fold $(\mathrm{P}<0.05$; Figure $4 \mathrm{~A})$ suggesting NCOA1 mRNA to be regulated by $\mathrm{P}_{4}$ directly. However, protein expression for NCOA1 increased significantly after $\mathrm{LH} / \mathrm{P}_{4}$ depletion ( 1 vs $2.38 \pm 0.04$ fold, VEH vs CET treatment; $\mathrm{P}<0.05$ ) (Figure 4B), but no significant change was observed following $\mathrm{P}_{4}$ replacement $(\mathrm{P}>0.05)$. Messenger levels of NCOA2 and FKBP5 in CL tissue did not significantly change after $\mathrm{LH} / \mathrm{P}_{4}$ depletion or $\mathrm{P}_{4}$ replacement $(\mathrm{P}>0.05$; Figure $4 \mathrm{~A})$. On the other hand, the protein expression for NCOA2 was significantly $(\mathrm{P}<0.05)$ higher after $\mathrm{LH} / \mathrm{P}_{4}$ depletion ( 1 vs $1.87 \pm 0.05$ fold, VEH vs CET treatment; $\mathrm{P}<0.05)$. However, $\mathrm{P}_{4}$ replacement resulted in significant decrease in protein levels ( 1 vs $0.38 \pm 0.10$ fold, $\mathrm{VEH}$ vs $\mathrm{CET}+\mathrm{P}_{4}$ treatment; $\left.\mathrm{P}<0.05\right)$ compared to $\mathrm{CL}$ obtained from $\mathrm{VEH}$ or CET treated monkeys indicating indirect/direct regulation of NCOA2 by $\mathrm{P}_{4}$ at the protein level. Messenger levels of NCOA3 in CL tissue did not change significantly after $\mathrm{LH} / \mathrm{P}_{4}$ depletion or $\mathrm{P}_{4}$ replacement ( $\mathrm{P}>0.05$; Figure $4 \mathrm{~A})$. However, the protein expression for NCOA3 was low in CL from VEH treated monkeys and increased significantly after $\mathrm{LH} / \mathrm{P}_{4}$ depletion ( 1 vs $3.10 \pm 0.50$ fold, VEH vs CET treatment; $\mathrm{P}<0.05$ ) while decreased after $\mathrm{P}_{4}$ replacement (Figure 4B) suggesting a role for $\mathrm{P}_{4}$ in the regulation of NCOA3 protein 


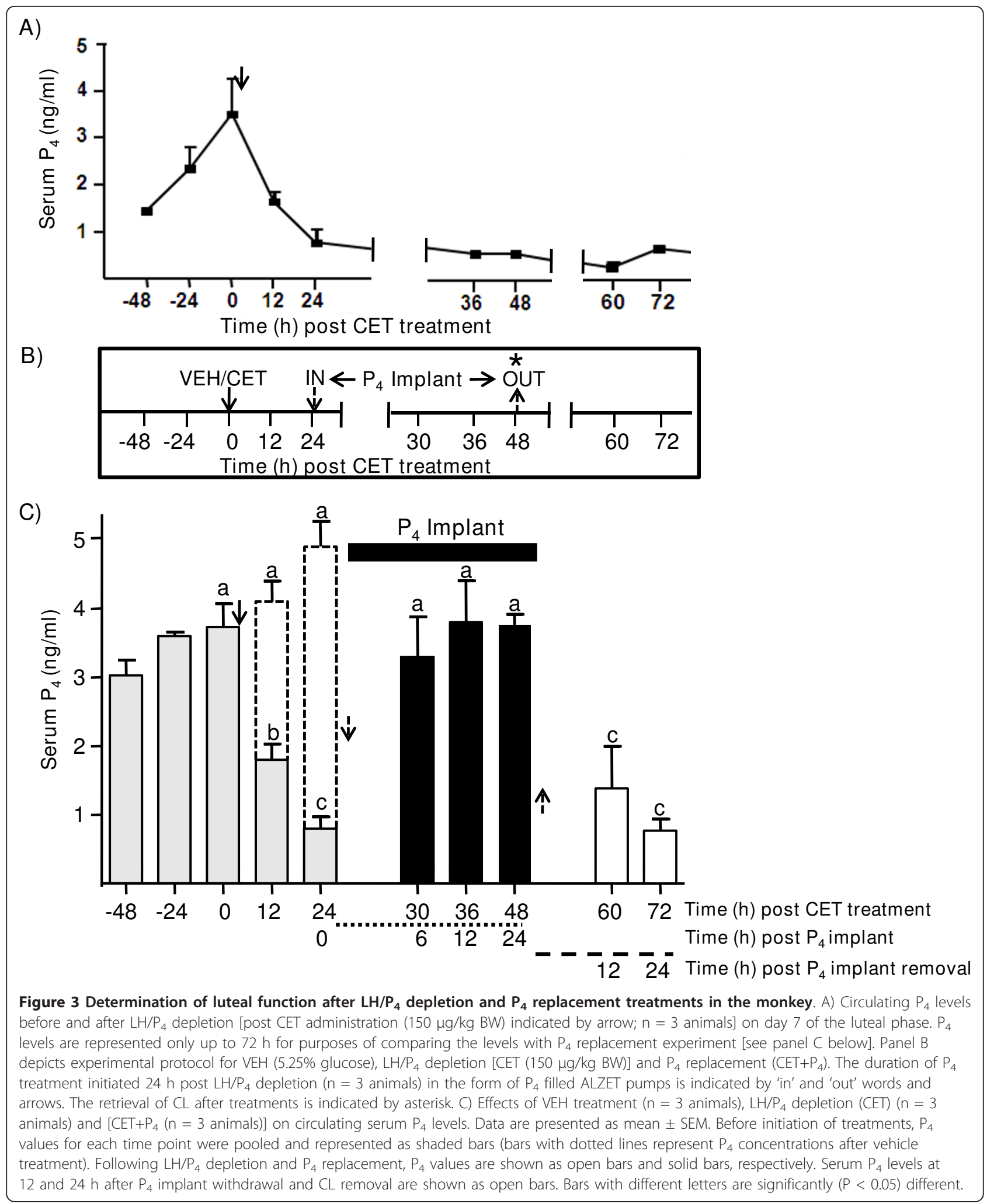


A)
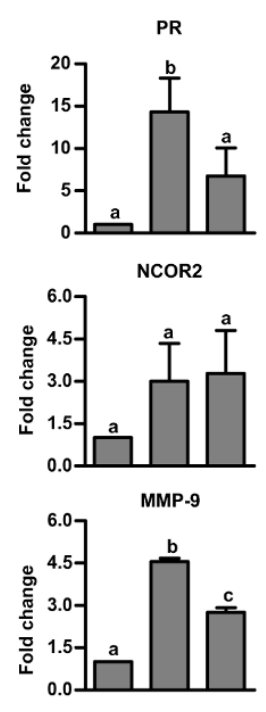

BMP5

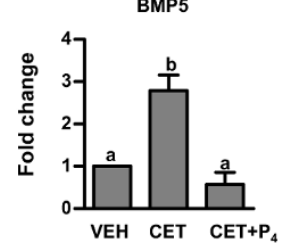

NCOA1
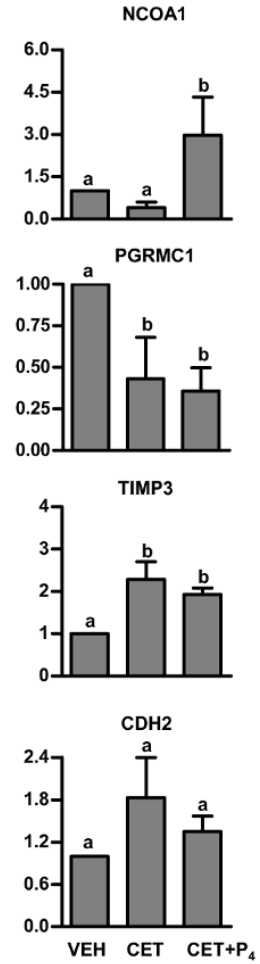
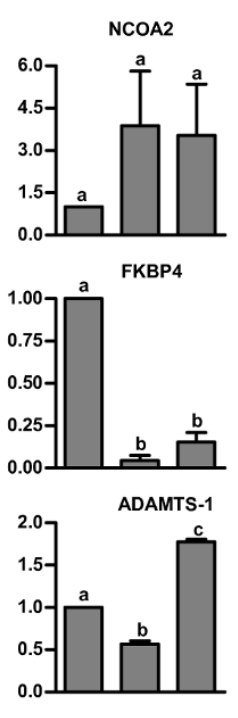

HOXA1
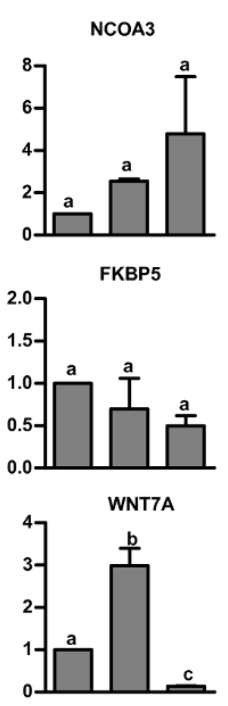

IHH

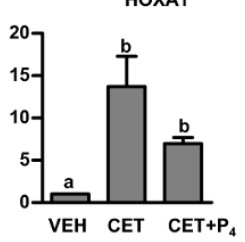

B)
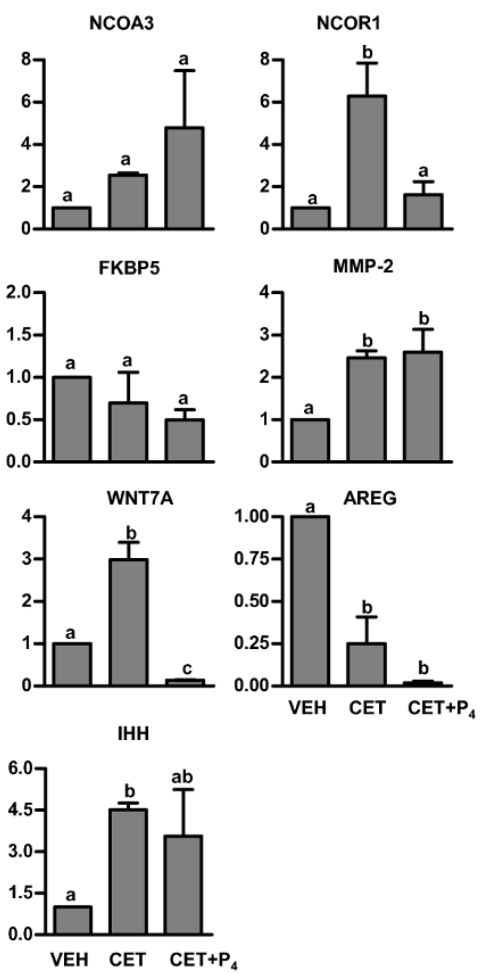

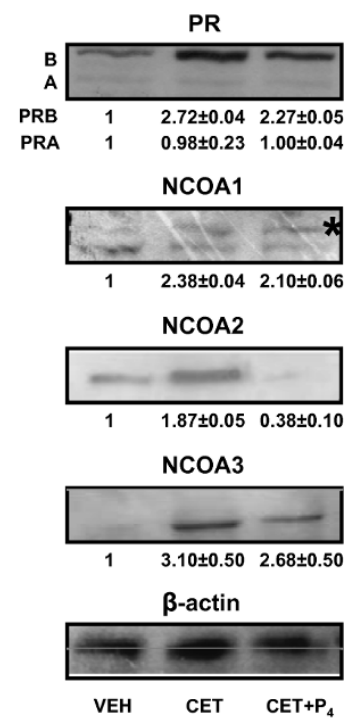

Figure 4 Analysis of expression of genes associated with $\mathrm{PR}$, its cofactors and $\mathrm{P}_{4}$ target genes in $\mathrm{CL}$ of monkeys treated with VEH (5.25\% glucose injection at mid luteal phase), CET (LH/ $\mathbf{P}_{\mathbf{4}}$ depletion) and CET+ $\mathbf{P}_{\mathbf{4}}$ ( $\mathbf{P}_{\mathbf{4}}$ replacement). A) Real time RT-PCR expression analysis of various genes associated with PR signaling and its target genes. The fold expression change for VEH group was set as 1 and values for other groups were expressed in relation to the VEH group. For details on fold change calculation for real time RT-PCR analysis, see legend to Figure 1. Bars with different letters are significantly $(P<0.05)$ different for the individual genes examined. B) Immunoblot analysis of PR, NCOA1, $\mathrm{NCOA} 2$ and NCOA3 proteins in $\mathrm{CL}$ after $\mathrm{LH} / \mathrm{P}_{4}$ depletion and $\mathrm{P}_{4}$ replacement. Immunoblots are analyzed by densitometry and densitometric value for VEH group is set as 1 fold and values for other groups were expressed in relation to the VEH group. For NCOA1 protein, the upper band indicated by asterisk was considered for densitometric analysis.

levels. The fold change in expression of NCOR1 mRNA increased significantly 5-8 fold after $\mathrm{LH} / \mathrm{P}_{4}$ depletion and became lower following $\mathrm{P}_{4}$ replacement $(\mathrm{P}<0.05$; Figure 4A). Similarly expression of NCOR2 mRNA increased (but not statistically significant) after $\mathrm{LH} / \mathrm{P}_{4}$ depletion, but had no effect following $\mathrm{P}_{4}$ replacement (Figure 4A). Expression of WNT7A mRNA increased significantly $(\mathrm{P}<$ 0. 05; Figure 4A) after $\mathrm{LH} / \mathrm{P}_{4}$ depletion, and the expression decreased significantly $(\mathrm{P}<0.05)$ after $\mathrm{P}_{4}$ replacement demonstrating regulation of WNT7A mRNA by $\mathrm{P}_{4}$. Expression of AREG mRNA decreased significantly $(\mathrm{P}<$ 0.05) after $\mathrm{LH} / \mathrm{P}_{4}$ depletion and remained low post $\mathrm{P}_{4}$ replacement (Figure 4A). The fold change in expression of BMP5 increased 3 fold after $\mathrm{LH} / \mathrm{P}_{4}$ depletion, but the expression decreased significantly $(\mathrm{P}<0.05)$ upon $\mathrm{P}_{4}$ replacement (Figure 4A) suggesting BMP5 gene to be a $\mathrm{P}_{4}$ responsive gene. Though the fold change in expression of cadherin $(\mathrm{CDH} 2)$ tended to be higher (but not statistically significant) after $\mathrm{LH} / \mathrm{P}_{4}$ depletion showed no significant change after $\mathrm{P}_{4}$ replacement (Figure 4A). Expression of HOXA1 and IHH mRNA were increased significantly $(\mathrm{P}<$ $0.05)$ after $\mathrm{LH} / \mathrm{P}_{4}$ depletion, while expression of HOXA1 mRNA decreased after $\mathrm{P}_{4}$ replacement, expression of $\mathrm{IHH}$ mRNA did not change significantly after $\mathrm{P}_{4}$ replacement (Figure 4A).

The fold expression change of ADAMTS-1 mRNA after $\mathrm{LH} / \mathrm{P}_{4}$ depletion was lower compared to $\mathrm{VEH}$ treatment $(\mathrm{P}<0.05)$ and the expression increased significantly $(\mathrm{P}<0.05)$ following $\mathrm{P}_{4}$ replacement (Figure $\left.4 \mathrm{~A}\right)$. Fold change in expression of MMP-9 mRNA increased post $\mathrm{LH} / \mathrm{P}_{4}$ depletion, and decreased significantly post $\mathrm{P}_{4}$ replacement $(\mathrm{P}<0.05$; Figure $4 \mathrm{~A})$ indicating indirect/ direct regulation of both ADAMTS-1 and MMP-9 mRNAs by $\mathrm{P}_{4}$ at the transcription level. Further, the fold change in expression of other genes like MMP-2 and TIMP3 increased significantly following $\mathrm{LH} / \mathrm{P}_{4}$ 
depletion, but $\mathrm{P}_{4}$ replacement had no effect $(\mathrm{P}<0.05$; Figure 4A).

Analysis of luteal tissue lysates for changes in P38 activation indicated that $\mathrm{P} 38$ activity was lower in $\mathrm{CL}$ after $\mathrm{LH} / \mathrm{P}_{4}$ depletion, however, $\mathrm{P}_{4}$ replacement increased P38 activation significantly $(P<0.05$; Figure 5$)$. In vitro MAPK assays revealed lower levels of pATF-2, a substrate for activated P38 kinase, in CL after $\mathrm{LH} / \mathrm{P}_{4}$ depletion, whereas, the effect of $\mathrm{LH} / \mathrm{P}_{4}$ depletion on pATF-2 levels was prevented by $\mathrm{P}_{4}$ replacement (Figure 5). The kinetics of P38 activation was correlated with activation of its upstream kinase, pMKK3/6 protein levels. $\mathrm{LH} / \mathrm{P}_{4}$ depletion decreased the $\mathrm{pMKK} 3 / 6$ protein expression significantly $(\mathrm{P}<0.05)$, while $\mathrm{P}_{4}$ replacement increased its levels significantly $(\mathrm{P}<0.05$; Figure 5$)$ indicating other components of MAP kinase signaling to be active post $\mathrm{P}_{4}$ replacement. Expression of other MAP kinase like ERK

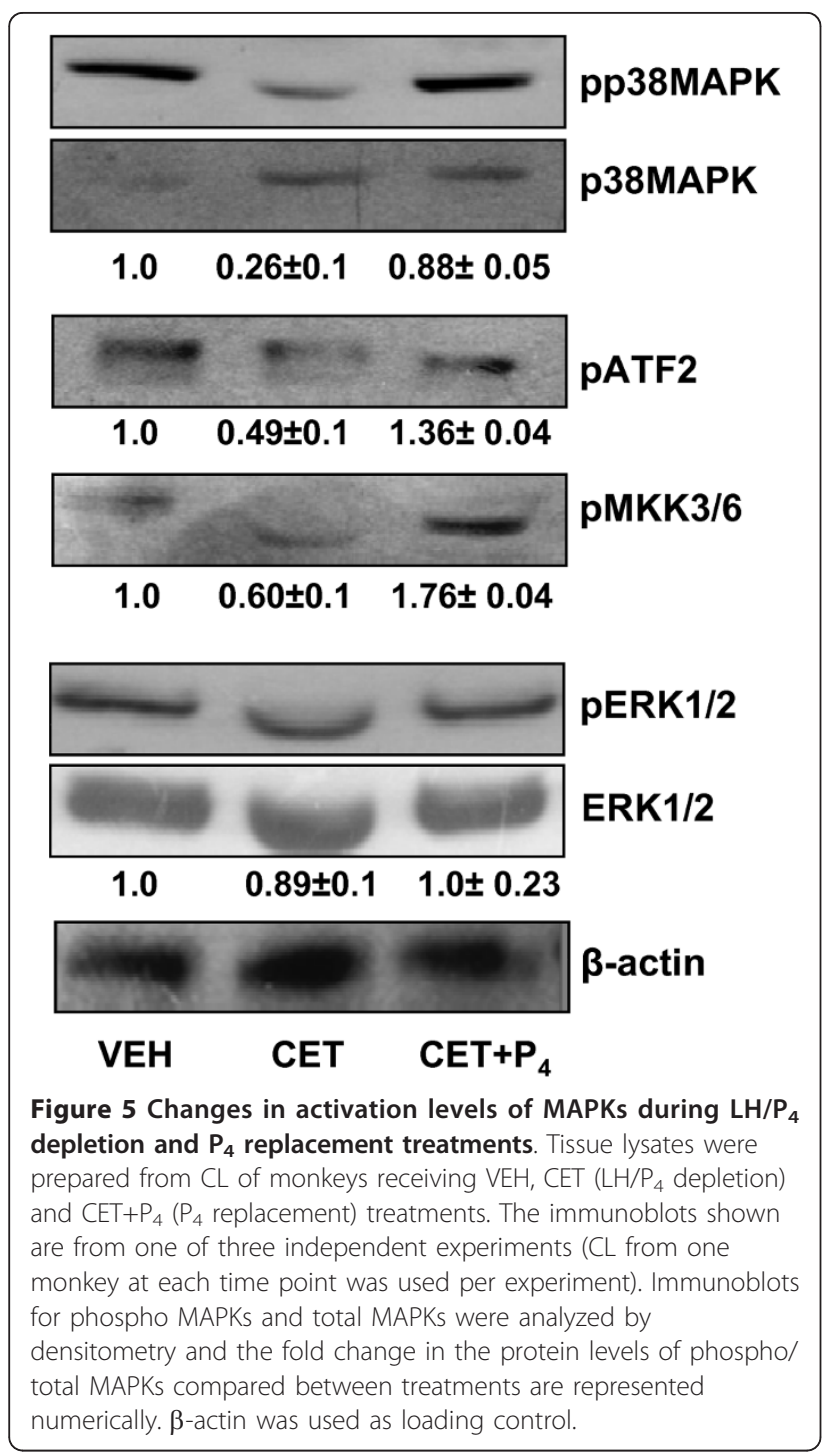

was also determined. Phosphorylated ERK levels did not change significantly in $\mathrm{CL}$ tissues both after $\mathrm{LH} / \mathrm{P}_{4}$ depletion and $\mathrm{P}_{4}$ replacement ( $\mathrm{P}>0.05$; Figure 5).

\section{Effects of $\mathrm{P}_{4}$ supplementation on gene expression changes during the late luteal phase}

Circulating $\mathrm{P}_{4}$ concentrations in monkeys before and after implantation of $\mathrm{P}_{4}$ containing ALZET pumps and in untreated control monkeys are shown in Figure 6A. Implantation of $\mathrm{P}_{4}$ pumps resulted in significant $(\mathrm{P}<0.05)$ increase in concentrations of $\mathrm{P}_{4}$ i.e., $4.4 \pm 0.64,4.2 \pm 0.37$, $4.4 \pm 0.35 \mathrm{ng} / \mathrm{ml}$ at $6,12,24 \mathrm{~h}$ post $\mathrm{P}_{4}$ supplementation, respectively and the corresponding $\mathrm{P}_{4}$ concentrations from untreated control monkeys were $0.70 \pm 0.1,0.6 \pm 0.1$ and $0.49 \pm 0.03 \mathrm{ng} / \mathrm{ml}$ at 6,12 and $24 \mathrm{~h}$, respectively (Figure 6A). Real time RT-PCR analysis showed $>2$ fold up regulation of PR, NCOA1, NCOA3, NCOR2, FKBP4, FKBP5, $\mathrm{CDH} 2$, HOXA1 and AREG expression in $\mathrm{P}_{4}$ supplemented monkeys, while expression of BMP5, MMP-2, PGRMC1, and ADAMTS- 1 was significantly down regulated $(\mathrm{P}<$ 0.05 ; Figure $6 \mathrm{~B}$ ). Immunoblot analysis for PR (both isoforms $A \& B$ ) protein showed no significant change after $P_{4}$ supplementation, whereas, immunoblot analysis for NCOA1 and NCOA2 proteins showed significantly lower $(\mathrm{P}<0.05)$ expression after $\mathrm{P}_{4}$ supplementation $(\mathrm{NCOA} 1,1$ vs $0.25 \pm 0.2$ fold, for NCOA2; 1 vs $0.62 \pm 0.2$ fold; Figure $6 C)$. Immunoblot analysis for protein expression of NCOA3 and MMP-9 showed lower levels after $\mathrm{P}_{4}$ supplementation (not statistically significant $\mathrm{P}>0.05$; Figure $6 \mathrm{C}$ ).

\section{Discussion}

Together with earlier reports for presence of PR in CL of many other species, the results of expression of PR, various binding proteins, cofactors and $\mathrm{P}_{4}$ regulation of expression of few genes in the present study further confirm $\mathrm{P}_{4}$ actions within the $\mathrm{CL}$. The importance of $\mathrm{P}_{4}$ in the regulation of $\mathrm{CL}$ structure and function has been demonstrated in rats. It was shown that $\mathrm{P}_{4}$ administration during postpartum period had an anti apoptotic action in the CL [9]. Although the rat CL does not express nuclear PR, it was suggested that $\mathrm{P}_{4}$ mediates its action by binding to its membrane receptors [30]. In recent years, the membrane receptor-mediated actions of $\mathrm{P}_{4}$ appear to have emerged as an important mechanism for activation of $\mathrm{P}_{4}$ signal transduction pathway. It was reported that rat luteal cells express membrane and progestin binding proteins, progestin membrane receptor (PMR) $\alpha$, PMR $\beta$, PMR $\gamma$, membrane component 1 (PRMC1/PGMRC1) and Rda 288 [30]. In a recent study, it was demonstrated that PGMRC1-dependent mechanism appears to promote human granulose/luteal cell survival [31] confirming the novel membrane-bound progestin receptors with defined actions. In the present study, expression of PGRMC1 was demonstrated in the 


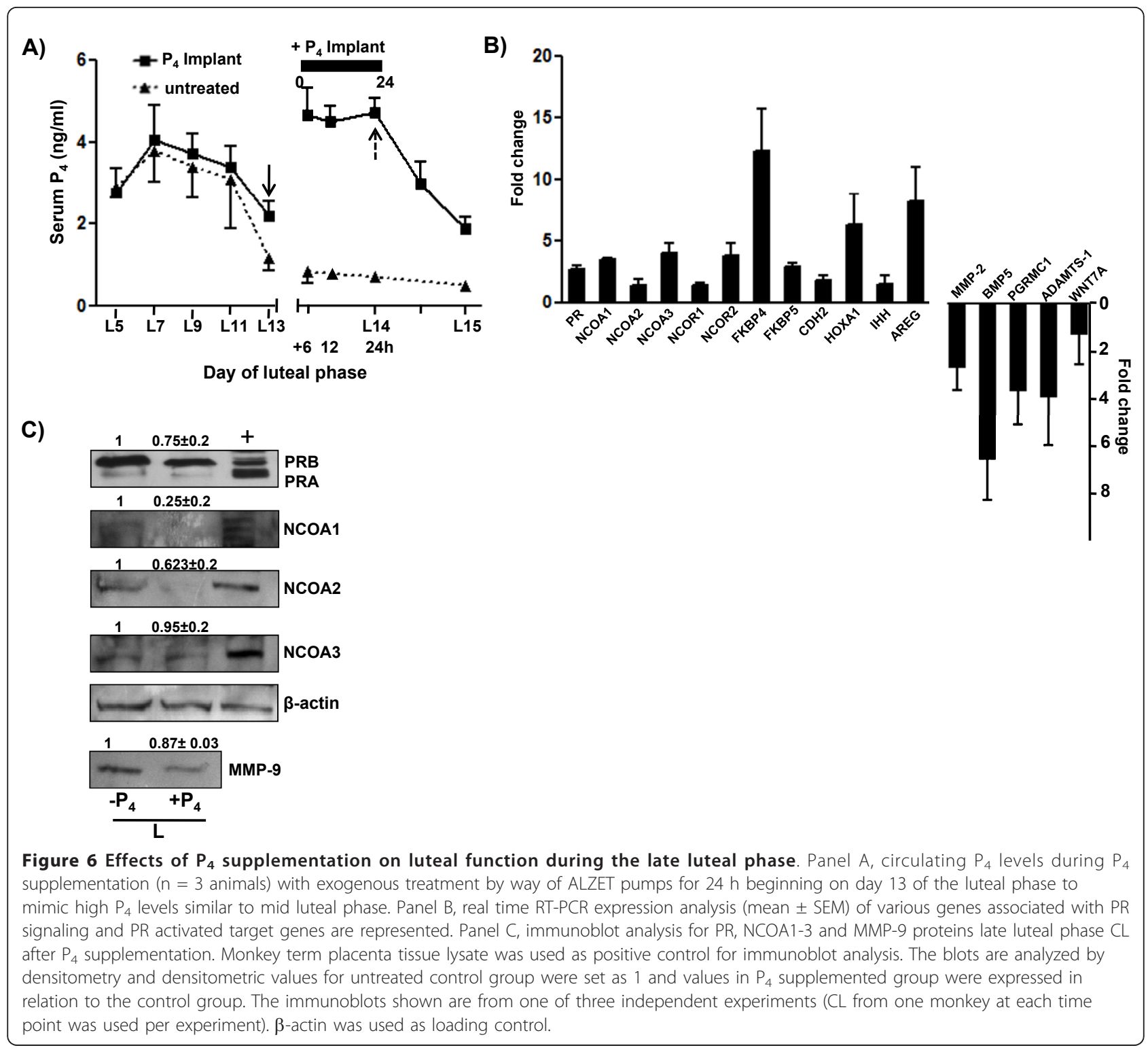

$\mathrm{CL}$ and its expression became lower after $\mathrm{LH} / \mathrm{P}_{4}$ depletion. This finding was similar to the earlier observation reported previously in the rhesus macaque [6]. Further restoration of PGRMC1 expression was observed after $\mathrm{LH}$ replacement in $\mathrm{LH} / \mathrm{P}_{4}$ ablated rhesus macaque [6]. In contrast, in the present study PGRMC1 expression was not restored following $\mathrm{LH}$ replacement in $\mathrm{LH} / \mathrm{P}_{4}$ depleted monkeys. The difference in the findings between the two studies could be attributed to differences in the treatment protocols employed and/or differences in the response to LH replacement observed between the two macaques.

Rothchild [2] aptly described CL as the most unique endocrine gland in the body, since there appears to be large interspecies variations in the mechanisms of regulation of its function. In higher primates, it is well established that the sole trophic stimulus for $\mathrm{P}_{4}$ secretion is the pulsatile secretion of pituitary LH. It is possible that $\mathrm{P}_{4}$ may not have an important role in its own secretion, but it might have an important role in maintaining structural integrity of the CL capable of responding to the luteotrophic stimulus. Hutchison and Zeleznik [32] demonstrated the rescue of CL function in the hypothalamus lesioned monkeys after reestablishment of pulsatile GnRH treatment indicating the resilience of CL tissue to the deprivation of luteotrophic support for long periods. In our studies, it was confirmed that $\mathrm{CL}$ was responsive to luteotrophic support for up to $48 \mathrm{~h}$ following inhibition of pituitary LH secretion [16]. We utilized $\mathrm{LH} / \mathrm{P}_{4}$ depleted and LH replacement model systems that did not 
require extreme surgical procedures, yet allow examining the $\mathrm{CL}$ function during $\mathrm{LH} / \mathrm{P}_{4}$ depletion period as well as hormone replacement period. During induced luteolysis, even though LH replacement had profound effects on expression of several genes [16], but this could be the result of both direct as well as indirect effects of LH. In the present study, examination of direct effects of $\mathrm{P}_{4}$ on CL tissue revealed changes in expression of PR and NCOR1, but expression of many other genes involved in PR activation were not significantly affected. Since, the duration of $\mathrm{P}_{4}$ replacement lasted only for $24 \mathrm{~h}$, for the effect to be apparent a longer duration of $\mathrm{P}_{4}$ replacement might be required. Alternatively, perhaps the effects of $\mathrm{P}_{4}$ on expression of genes may be observed only when high intraluteal $\mathrm{P}_{4}$ levels as seen in functional $\mathrm{CL}$ is achieved. In the present study, only circulating $\mathrm{P}_{4}$ levels were mimicked but more studies are required to achieve the high intra luteal $\mathrm{P}_{4}$ levels and determine its effect on the luteal expression of genes.

Tissue proteinases and genes associated with tissue remodelling namely, TIMPs, MMPs and ADAMTS- 1 have been examined in the CL tissues of higher primates. In the present study, the findings of higher expression of TIMP3 and MMP-9 was observed during latter part of the luteal phase which is in accordance with similar findings reported for $\mathrm{CL}$ of the rhesus macaque [18]. It was previously reported that ADAMTS-1 expression was high in early CL but declined thereafter at other stages of the luteal phase in the rhesus macaque [22]. In the present study, however, no discernible pattern of expression of ADAMTS-1 was observed during the luteal phase. It should be pointed out that in the rhesus macaque the highest expression was seen only at day 2 of the luteal phase, while in the present study the day $2 \mathrm{CL}$ was not examined. Treatment with GnRH R antagonists [i.e. LH/ $\mathrm{P}_{4}$ depletion models] in both the macaques resulted in decreased expression of ADAMTS-1 at mid luteal phase. Interestingly, LH replacement, but not steroid replacement, prevented the decreased ADAMTS-1 expression seen after GnRH R antagonist treatment in the rhesus macaque, but in the present study both LH (observed only in real time RT-PCR analysis) and $\mathrm{P}_{4}$ replacement treatments restored or increased its expression. The reason for different findings on ADAMTS- 1 expression after $\mathrm{P}_{4}$ (in the present study) or progestin (rhesus monkey; [22]) treatments is difficult to explain and perhaps, related to treatment protocol employed in both these studies. Also, the unexpected decrease in ADAMTS-1 expression seen after $\mathrm{P}_{4}$ supplementation at late luteal phase observed in the present study is difficult to explain. Additional experiments are necessary to address the regulation of ADAMTS- 1 expression in the CL by LH and $\mathrm{P}_{4}$.

Stouffer and Young, 2004 [19] reported a differential expression of MMP-9 with regulation of its expression to be at different levels involving both transcriptional and translational mechanisms in the CL of the rhesus macaque. In the present study, expression of MMP-9 in $\mathrm{LH} / \mathrm{P}_{4}$ depletion and $\mathrm{LH}$ replacement studies remained high, but $\mathrm{P}_{4}$ replacement decreased its expression, suggesting MMP-9 expression appear to be regulated by $\mathrm{P}_{4}$. In accordance with our data, regulation of MMP-9 expression by $\mathrm{P}_{4}$ had been reported by other investigations in studies involving human endometrial explants and rabbit cervix [33,34]. It should be pointed out that MMP-9 expression during spontaneous luteolysis [data not shown] and $\mathrm{P}_{4}$ supplementation during late luteal phases did not show significant change indicating that regulation of MMP-9 expression may be dependent on circulating $\mathrm{LH}$ as well as $\mathrm{P}_{4}$ concentrations. The decrease in expression of MMP- 2 mRNA post $\mathrm{P}_{4}$ replacement during late luteal phase was similar to the reported decrease in MMP-2 expression in the human $\mathrm{CL}$ after treatment with hCG to mimic early pregnancy [20]. It is possible that $\mathrm{LH}$ and $\mathrm{P}_{4}$ may synergistically act to regulate MMP- 2 mRNA expression during the late luteal phase following $\mathrm{P}_{4}$ replacement as both are present in this model system, however, the molecular mechanisms for this synergistic action needs to be clarified. Decreased expression of pro-MMP-9, pro-MMP-2 and MMP-2 in endometrial cancer cell lines after in vitro administration of medroxy progesterone acetate, an synthetic progesterone preparation, [35] suggests that ECM remodelling could well be controlled by $\mathrm{P}_{4}$ as well as by $\mathrm{LH}$ in the CL tissue.

Expression of WNT7A, AREG, BMP5, HOXA1 and $\mathrm{IHH}$, which are regarded as $\mathrm{P}_{4}$ target genes in uterus and mammary gland were examined in the CL after LH/ $\mathrm{P}_{4}$ depletion and $\mathrm{P}_{4}$ replacement. WNT7A coordinates a variety of cell and developmental pathways and reported to guide hormonal responses during postnatal uterine growth [36]. In the present study, the observation that $\mathrm{P}_{4}$ decreased WNT7A expression was similar to finding reported in the uterus [25]. The observation of down regulated expression of BMP5 upon $\mathrm{P}_{4}$ replacement in the present study is consistent with the findings in uterus. Both WNT7A and BMP5 pathways appear to be interlinked since BMPs are shown to be induced by WNT signaling in the neurons [37]. BMPs have been shown to stimulate steroidogenesis and proliferation in porcine theca cells [38], but the role of $\mathrm{P}_{4}$ regulated WNT and BMP genes on the structure and function of $\mathrm{CL}$ remains to be determined. The observation of low levels of phosphorylated P38 in CL post $\mathrm{LH} / \mathrm{P}_{4}$ depletion, and its reversal after $\mathrm{P}_{4}$ replacement are consistent with similar findings reported in uterus and mammary gland after $\mathrm{P}_{4}$ treatment in mice [39]. By activating the MAP kinase pathway, $\mathrm{P}_{4}$ appears to activate a unique biologically important molecule to control CL structure 
and function. It should be pointed out that changes in dynamics of MAP kinase activities have been shown to regulate CL function [27]. PR is known to be phosphorylated by various kinases including MAP kinases in response to various physiological stimuli [40]. The activation of MAP kinases have been shown to regulate expression and function of coactivators like NCOA1 [39] and NCOA3 [41]. Ligand-mediated down regulation and extensive loss of nuclear steroid receptor protein is well recognized and during this process, different phosphorylation pathways may affect the proteasomemediated degradation of nuclear receptors including PR [40]. It is reported that NCOA3 is phosphorylated by P38 and the phosphorylated NCOA3 is subjected to degradation by proteasome [42]. Whether activation of P38 by $\mathrm{P}_{4}$ would have a role in regulating similar processes in the CL tissue remains to be addressed, however, the results in the present study suggest operation of similar mechanism. Gene expression analysis of 19 genes belonging to $\mathrm{PR}$ signaling during $\mathrm{LH} / \mathrm{P}_{4}$ depletion and $\mathrm{P}_{4}$ replacement experiments revealed expression of 8 genes [(PR, NCOA1, NCOR1, WNT7A, BMP5, HOXA1, ADAMTS-1 and MMP-9) and protein expression of 3 genes] to be directly regulated by $\mathrm{P}_{4}$. The expression of other 11 genes appear to be regulated by both $\mathrm{LH}$ and $\mathrm{P}_{4}$ in the CL (see Table 3). In order to further extend the observations of direct actions of $\mathrm{P}_{4}$ and to further delineate role of $\mathrm{P}_{4}$ in the regulation of CL function, circulating $\mathrm{P}_{4}$ concentrations were increased for $24 \mathrm{~h}$ to mimic early pregnancy levels during the late luteal phase of the non fertile cycle. Expression of many of the genes examined was observed to be differentially expressed indicating that $\mathrm{P}_{4}$ may have an important role in the regulation of $\mathrm{CL}$ function during early pregnancy. Also, it should be pointed out that the general housekeeping activity that include anti-apoptotic actions, structural integrity of luteal cells and perhaps regulation of expression of few genes associated with overall maintenance of $\mathrm{CL}$ structure may be attributed to direct or indirect actions of $\mathrm{P}_{4}$.

In summary, experiments were performed to examine direct effects of $\mathrm{P}_{4 \leftarrow}$ on the regulation of expression of genes in the monkey CL. The first experiment comprised of analysis of previously published microarray data to identify differentially expressed genes considered as target of $\mathrm{P}_{4}$ action and validation of some of these genes by real time RT-PCR analysis. In the second experiment, expression of many of the genes identified in the first experiment was examined throughout the luteal phase. In the third experiment, the direct effects

Table 3 List of genes whose expression identified to be regulated by $\mathbf{P}_{\mathbf{4}}$ treatment

\begin{tabular}{|c|c|c|c|c|c|}
\hline \multirow[t]{2}{*}{ Sl. No. } & \multicolumn{2}{|r|}{ Gene } & \multicolumn{2}{|c|}{ Changes in levels after } & \multirow[t]{2}{*}{ Regulation by $P_{4}$} \\
\hline & & & $\mathrm{LH} / \mathrm{P}_{4}$ depletion & $\mathrm{P}_{4}$ replacement & \\
\hline \multirow[t]{3}{*}{1} & $P R$ & mRNA & up & down & $\mathrm{Y}$ \\
\hline & & Protein (PR B) & up & down & Y \\
\hline & & Protein (PR A) & - & - & $N$ \\
\hline \multirow[t]{2}{*}{2} & NCOA1 & mRNA & - & up & $N$ \\
\hline & & Protein & up & - & N \\
\hline \multirow[t]{2}{*}{3} & NCOA2 & mRNA & - & - & $N$ \\
\hline & & Protein & up & down & Y \\
\hline \multirow[t]{2}{*}{4} & NCOA3 & mRNA & - & - & N \\
\hline & & Protein & up & down & Y \\
\hline 5 & & PGRMC1 & down & - & $N$ \\
\hline 6 & & FKBP4 & down & - & N \\
\hline 7 & & FKBP5 & - & - & N \\
\hline 8 & & NCOR1 & up & down & Y \\
\hline 9 & & NCOR2 & up & - & $N$ \\
\hline 10 & & WNT7A & up & down & Y \\
\hline 11 & & AREG & down & down & N \\
\hline 12 & & BMP5 & up & down & Y \\
\hline 13 & & $\mathrm{CDH} 2$ & up & - & $\mathrm{N}$ \\
\hline 14 & & HOXA1 & up & down & Y \\
\hline 15 & & $\mathbb{H H}$ & up & - & $N$ \\
\hline 16 & & ADAMTS1 & down & up & Y \\
\hline 17 & & MMP9 & up & down & Y \\
\hline 18 & & MMP2 & up & - & N \\
\hline 19 & & TIMP3 & up & - & $N$ \\
\hline
\end{tabular}


of $\mathrm{P}_{4 \leftarrow}$ on expression of many of these genes was examined following $\mathrm{P}_{4 \leftarrow}$ replacement in monkeys depleted for circulating endogenous $\mathrm{LH}$ and $\mathrm{P}_{4 \leftarrow}$ by way of inhibition of pituitary gonadotropin secretion. In the fourth experiment, the effects of $\mathrm{P}_{4 \leftarrow}$ supplementation on expression of genes during the late luteal phase with declining endogenous $\mathrm{P}_{4 \leftarrow}$ levels were examined. This experiment was done to determine whether increased $\mathrm{P}_{4 \leftarrow}$ seen during early pregnancy regulate expression of these genes. The results from these studies indicated that $\mathrm{P}_{4 \leftarrow}$ appears to regulate expression of many of the genes in the CL.

\section{Conclusions}

Experiments were carried out to assess the direct effects of $\mathrm{P}_{4}$ on CL function in monkeys. Expression of some of the genes involved in PR signaling and genes considered as targets of $\mathrm{LH}$ and $\mathrm{P}_{4}$ was analyzed in $\mathrm{LH} / \mathrm{P}_{4}$ depletion and $\mathrm{P}_{4}$ replacement model as well as $\mathrm{P}_{4}$ supplementation model during the late luteal phase, and the results indicated that expression of number of genes appeared to be regulated directly or indirectly by $\mathrm{P}_{4}$. These results suggest that replacement of $\mathrm{P}_{4}$ during $\mathrm{LH} / \mathrm{P}_{4}$ depletion (induced luteolysis model) is suitable for assessing the effects of $\mathrm{P}_{4}$ on $\mathrm{CL}$ function. Further, these studies suggest that CL could serve as a target tissue for examining genomic and non genomic actions of $\mathrm{P}_{4}$.

\section{Acknowledgements \\ We are grateful to Dr. Basavanagouda and staff of Primate Research Laboratory for assistance with surgeries and Mr. Kunal BS for help rendered in the preparation of MS. Financial support from Department of Biotechnology, Government of India, to conduct these studies is gratefully acknowledged.}

\section{Authors' contributions}

PS and RM participated in designing, conducting experiments, analysis of results and preparation of manuscript. KCJ participated in the preparation of manuscript. All authors read and approved the final manuscript.

\section{Competing interests}

The authors declare that they have no competing interests.

Received: 21 September 2010 Accepted: 3 February 2011

Published: 3 February 2011

\section{References}

1. Stouffer RL, Xu F, Duffy DM: Molecular control of ovulation and luteinization in the primate follicle. Front Biosci 2007, 12:297-307.

2. Rothchild $\mathrm{I}$ : The regulation of the mammalian corpus luteum. Recent Prog Horm Res 1981, 37:183-298.

3. Rothchild I: The corpus luteum revisited: are the paradoxical effects of RU486 a clue to how progesterone stimulates its own secretion? Biol Reprod 1996, 55(1):1-4.

4. Stouffer RL, Duffy DM: Receptors for sex steroids in the primate corpus luteum New insight into gonadotropin and steroid action. Trends Endocrinol Metab 1995, 6(3):83-89.

5. Stouffer RL: Progesterone as a mediator of gonadotrophin action in the corpus luteum: beyond steroidogenesis. Hum Reprod Update 2003, 9(2):99-117.

6. Bishop CV, Hennebold JD, Stouffer RL: The effects of luteinizing hormone ablation/replacement versus steroid ablation/replacement on gene expression in the primate corpus luteum. Mol Hum Reprod 2009, 15(3):181-193.

7. Engmann L, Losel R, Wehling M, Peluso JJ: Progesterone regulation of human granulosa/luteal cell viability by an RU486-independent mechanism. J Clin Endocrinol Metab 2006, 91(12):4962-4968.

8. Goyeneche AA, Calvo V, Gibori G, Telleria CM: Androstenedione interferes in luteal regression by inhibiting apoptosis and stimulating progesterone production. Biol Reprod 2002, 66(5):1540-1547.

9. Goyeneche AA, Deis RP, Gibori G, Telleria CM: Progesterone promotes survival of the rat corpus luteum in the absence of cognate receptors. Biol Reprod 2003, 68(1):151-158.

10. Telleria CM, Goyeneche AA, Cavicchia JC, Stati AO, Deis RP: Apoptosis induced by antigestagen RU486 in rat corpus luteum of pregnancy. Endocrine 2001, 15(2):147-155.

11. Okuda K, Korzekwa A, Shibaya M, Murakami S, Nishimura R, Tsubouchi M, Woclawek-Potocka I, Skarzynski DJ: Progesterone is a suppressor of apoptosis in bovine luteal cells. Biol Reprod 2004, 71(6):2065-2071.

12. Rueda BR, Hendry IR, Hendry IW, Stormshak F, Slayden OD, Davis JS: Decreased progesterone levels and progesterone receptor antagonists promote apoptotic cell death in bovine luteal cells. Biol Reprod 2000, 62(2):269-276

13. McKenna NJ, O'Malley BW: Combinatorial control of gene expression by nuclear receptors and coregulators. Cell 2002, 108(4):465-474.

14. Wagner BL, Norris JD, Knotts TA, Weigel NL, McDonnell DP: The nuclear corepressors NCoR and SMRT are key regulators of both ligand- and 8-bromo-cyclic AMP-dependent transcriptional activity of the human progesterone receptor. Mol Cell Biol 1998, 18(3):1369-1378

15. Jackson TA, Richer JK, Bain DL, Takimoto GS, Tung L, Horwitz KB: The partial agonist activity of antagonist-occupied steroid receptors is controlled by a novel hinge domain-binding coactivator L7/SPA and the corepressors N-CoR or SMRT. Mol Endocrinol 1997, 11(6):693-705.

16. Priyanka S, Jayaram P, Sridaran R, Medhamurthy R: Genome-wide gene expression analysis reveals a dynamic interplay between luteotropic and luteolytic factors in the regulation of corpus luteum function in the bonnet monkey (Macaca radiata). Endocrinology 2009, 150(3):1473-1484.

17. Smith MF, Mclntush EW, Ricke WA, Kojima FN, Smith GW: Regulation of ovarian extracellular matrix remodelling by metalloproteinases and their tissue inhibitors: effects on follicular development, ovulation and luteal function. J Reprod Fertil Suppl 1999, 54:367-381.

18. Young KA, Hennebold JD, Stouffer RL: Dynamic expression of mRNAs and proteins for matrix metalloproteinases and their tissue inhibitors in the primate corpus luteum during the menstrual cycle. Mol Hum Reprod 2002, 8(9):833-840

19. Young KA, Stouffer RL: Gonadotropin and steroid regulation of matrix metalloproteinases and their endogenous tissue inhibitors in the developed corpus luteum of the rhesus monkey during the menstrual cycle. Biol Reprod 2004, 70(1):244-252.

20. Duncan WC, McNeilly AS, Illingworth PJ: The effect of luteal "rescue" on the expression and localization of matrix metalloproteinases and their tissue inhibitors in the human corpus luteum. J Clin Endocrinol Metab 1998, 83(7):2470-2478.

21. Suresh PS, Medhamurthy R: Dynamics of circulating concentrations of gonadotropins and ovarian hormones throughout the menstrual cycle in the bonnet monkey: role of inhibin $\mathrm{A}$ in the regulation of folliclestimulating hormone secretion. Am J Primatol 2009, 71(10):817-824.

22. Young KA, Tumlinson B, Stouffer RL: ADAMTS-1/METH-1 and TIMP-3 expression in the primate corpus luteum: divergent patterns and stagedependent regulation during the natural menstrual cycle. Mol Hum Reprod 2004, 10(8):559-565.

23. Robker RL, Russell DL, Espey LL, Lydon JP, O'Malley BW, Richards JS: Progesterone-regulated genes in the ovulation process: ADAMTS-1 and cathepsin L proteases. Proc Natl Acad Sci USA 2000, 97(9):4689-4694.

24. Peluso JJ, Liu X, Saunders MM, Claffey KP, Phoenix K: Regulation of ovarian cancer cell viability and sensitivity to cisplatin by progesterone receptor membrane component-1. J Clin Endocrinol Metab 2008, 93(5):1592-1599.

25. Jeong JW, Lee KY, Han SJ, Aronow BJ, Lydon JP, O'Malley BW, DeMayo FJ: The p160 steroid receptor coactivator 2, SRC-2, regulates murine endometrial function and regulates progesterone-independent and -dependent gene expression. Endocrinology 2007, 148(9):4238-4250.

26. Khatua A, Wang X, Ding T, Zhang Q, Reese J, DeMayo FJ, Paria BC: Indian hedgehog, but not histidine decarboxylase or amphiregulin, is a 
progesterone-regulated uterine gene in hamsters. Endocrinology 2006, 147(9):4079-4092.

27. Yadav VK, Medhamurthy R: Dynamic changes in mitogen-activated protein kinase (MAPK) activities in the corpus luteum of the bonnet monkey (Macaca radiata) during development, induced luteolysis, and simulated early pregnancy: a role for p38 MAPK in the regulation of luteal function. Endocrinology 2006, 147(4):2018-2027.

28. Ace $\mathrm{Cl}$, Okulicz WC: Microarray profiling of progesterone-regulated endometrial genes during the rhesus monkey secretory phase. Reprod Biol Endocrinol 2004, 2:54.

29. Richer JK, Jacobsen BM, Manning NG, Abel MG, Wolf DM, Horwitz KB: Differential gene regulation by the two progesterone receptor isoforms in human breast cancer cells. J Biol Chem 2002, 277(7):5209-5218.

30. Cai Z, Stocco C: Expression and regulation of progestin membrane receptors in the rat corpus luteum. Endocrinology 2005, 146(12):5522-5532

31. Peluso JJ, Liu X, Gawkowska A, Johnston-MacAnanny E: Progesterone activates a progesterone receptor membrane component 1-dependent mechanism that promotes human granulosa/luteal cell survival but not progesterone secretion. J Clin Endocrinol Metab 2009, 94(7):2644-2649.

32. Hutchison JS, Zeleznik AJ: The corpus luteum of the primate menstrual cycle is capable of recovering from a transient withdrawal of pituitary gonadotropin support. Endocrinology 1985, 117(3):1043-1049.

33. Imada K, Ito A, Sato T, Namiki M, Nagase H, Mori Y: Hormonal regulation of matrix metalloproteinase 9/gelatinase B gene expression in rabbit uterine cervical fibroblasts. Biol Reprod 1997, 56(3):575-580.

34. Marbaix E, Donnez J, Courtoy PJ, Eeckhout Y: Progesterone regulates the activity of collagenase and related gelatinases $A$ and $B$ in human endometrial explants. Proc Natl Acad Sci USA 1992, 89(24):11789-11793.

35. Di Nezza LA, Jobling T, Salamonsen LA: Progestin suppresses matrix metalloproteinase production in endometrial cancer. Gynecol Oncol 2003, 89(2):325-333.

36. Carta L, Sassoon D: Wnt7a is a suppressor of cell death in the female reproductive tract and is required for postnatal and estrogen-mediated growth. Biol Reprod 2004, 71(2):444-454

37. Kasai $M$, Satoh $K$, Akiyama $T$ : Wnt signaling regulates the sequential onset of neurogenesis and gliogenesis via induction of BMPs. Genes Cells 2005, 10(8):777-783.

38. Brankin V, Quinn RL, Webb R, Hunter MG: BMP-2 and -6 modulate porcine theca cell function alone and co-cultured with granulosa cells. Domest Anim Endocrinol 2005, 29(4):593-604.

39. Han SJ, Tsai SY, Tsai MJ, O'Malley BW: Distinct temporal and spatial activities of RU486 on progesterone receptor function in reproductive organs of ovariectomized mice. Endocrinology 2007, 148(5):2471-2486.

40. Lange CA, Shen T, Horwitz KB: Phosphorylation of human progesterone receptors at serine-294 by mitogen-activated protein kinase signals their degradation by the $26 \mathrm{~S}$ proteasome. Proc Natl Acad Sci USA 2000 97(3):1032-1037.

41. Wu RC, Qin J, Yi P, Wong J, Tsai SY, Tsai MJ, O'Malley BW: Selective phosphorylations of the SRC-3/AIB1 coactivator integrate genomic reponses to multiple cellular signaling pathways. Mol Cell 2004, 15(6):937-949.

42. Gianni M, Parrella E, Raska I Jr, Gaillard E, Nigro EA, Gaudon C, Garattini E, Rochette-Egly C: P38MAPK-dependent phosphorylation and degradation of SRC-3/AIB1 and RARalpha-mediated transcription. EMBO J 2006, 25(4):739-751

doi:10.1186/1477-7827-9-20

Cite this article as: Suresh et al:: The effect of progesterone replacement on gene expression in the corpus luteum during induced regression and late luteal phase in the bonnet monkey (Macaca radiata). Reproductive Biology and Endocrinology 2011 9:20.

\section{Submit your next manuscript to BioMed Central and take full advantage of:}

- Convenient online submission

- Thorough peer review

- No space constraints or color figure charges

- Immediate publication on acceptance

- Inclusion in PubMed, CAS, Scopus and Google Scholar

- Research which is freely available for redistribution

Submit your manuscript at www.biomedcentral.com/submit 